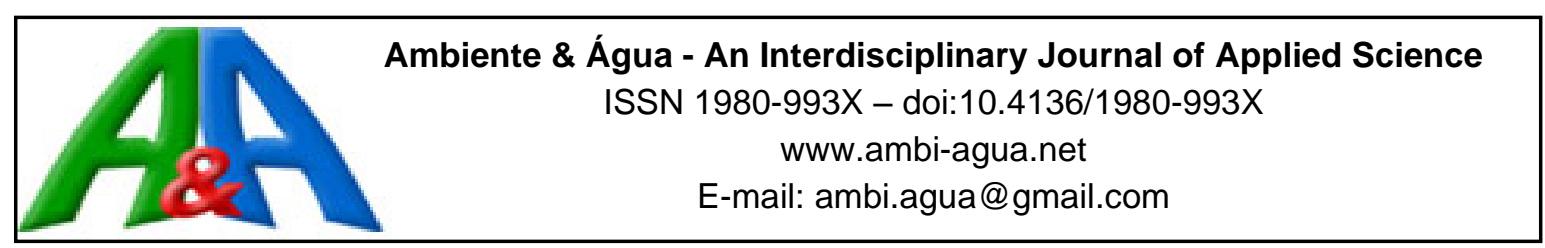

\title{
Function analysis of the calls of Dendropsophus microps of the Campos do Jordão State Park, São Paulo, Brazil
}

\author{
ARTICLES doi:10.4136/ambi-agua.2557
}

Received: 15 Aug. 2020; Accepted: 25 Sep. 2020

\author{
Maysa Hernandes Ricardo Toledo*iD; Itamar Alves Martins \\ Programa de Pós-Graduação em Ciências Ambientais (PPGCA). Universidade de Taubaté (UNITAU), \\ Estrada Municipal Doutor José Luiz Cembranelli, n5000, CEP: 12081-010, Taubaté, SP, Brazil. \\ E-mail: itamarmartins1@gmail.com \\ *Corresponding author. E-mail: maysa_hrtoledo@hotmail.com
}

\begin{abstract}
In this study, we describe the calls emitted by Dendropsophus microps, a species of frog in the family Hylidae, in Serra da Mantiqueira, Campos do Jordão, São Paulo, Brazil, and evaluate their functions in the social context using playback experiments. Between October 2016 and November 2017, 15 males of D. microps were recorded. Six hundred and five calls were analyzed and the existence of five types of call compositions was verified: simple call "A normal"; compound call "Af"; shorter "A" call + longer "A" call; "A + Af" calls; and simple call " $\mathrm{B}$ "; demonstrating the presence of compound calling in the vocalization structure. One thousand, six hundred and seventeen calls were recorded during the playback experiment in response to the 5 previously constructed stimuli. The " $\mathrm{B}$ " call was the most emitted in response to stimuli. The "A", "Af", "AA" and "AAf" stimuli caused visual signaling. We recorded a series of 4 to 5 "A" calls during agonistic interactions. Call "B" was identified as an advertisement call and calls "A", "Af", "AA" and "AAf" as aggressive calls. The presence of visual communication in addition to the acoustic communication of these individuals was also observed. The findings increase knowledge of the calling repertoire of this species and can be used in the future in other behavioral and taxonomic studies.
\end{abstract}

Keywords: bioacoustics, dendropsophinae, playback experiment.

\section{Análise da função dos cantos de Dendropsophus microps do Parque Estadual de Campos do Jordão, São Paulo, Brazil}

\section{RESUMO}

No presente estudo descrevemos as vocalizações emitidas por Dendropsophus microps na Serra da Mantiqueira, Campos do Jordão, São Paulo, Brasil e avaliamos suas funções no contexto social por meio de experimentos de playback. Entre outubro de 2016 a novembro de 2017 foram gravados 15 indivíduos machos de D. microps. Foram analisados 605 cantos e verificada a existência de cinco tipos de composições: canto simples "A normal"; canto composto "Af"; canto "A" mais curto + "A" mais longo; cantos "A +Af"; canto simples "B"; demonstrando a presença de canto composto na estrutura de vocalização. Foram gravados 1617 cantos durante o experimento de playback em resposta aos 5 estímulos previamente construídos. O canto " $\mathrm{B}$ " foi o mais emitido como respostas aos estímulos. Os estímulos " $\mathrm{A}$ ", "Af", "AA" e "AAf" ocasionaram sinalização visual. Registramos séries de 4 a 5 cantos "A" 
durante interações agonísticas. $\mathrm{O}$ canto " $\mathrm{B}$ " foi identificado como canto de anúncio e os cantos "A", "Af", "AA" e "AAf" como cantos agressivos. Também foi constatado a presença de comunicação visual além de comunicação acústica destes indivíduos. Os resultados encontrados aumentam o conhecimento acerca do canto dessa espécie, podendo ser usados futuramente em outros estudos comportamentais e taxonômicos.

Palavras-chave: bioacústica, dendropsophinae, experimento de playback.

\section{INTRODUCTION}

Among all aspects of anuran behaviour, acoustic communication stands out for its importance in reproductive biology and in the social context of this group (Wells, 2007). The advertisement call (sensu Wells, 1977) is the most emitted call, performed by males, mainly to attract co-specific females, also with an aggressive function in social behavior, having spectral and temporal characteristics for specific recognition (Wells, 2007).

Males have the ability to change these parameters and change the physical structure of the notes in order to emit a certain reproductive or aggressive acoustic behavior (Wells, 2007; Toledo and Haddad, 2009; Toledo et al., 2014). The identification of this vocal adjustment during the intraspecific competition and the identification of the advertisement call, is generally performed with playback experiments (Gerdhart and Huber, 2002). The playback experiments help in behavioral bioacoustics studies, and set the occurrence of different responses in the same type of vocalization, which allows the analysis and interpretation of acoustic and behavioral responses of male emitters (Giasson and Haddad, 2006; Wells, 2007).

The species of the Hylidae family (Rafinesque, 1815) present morphological and reproductive-behaviour variation and wide geographical distribution (Faivovich et al., 2005), which makes them good models for behavioral and social studies. Dendropsophus microps (Peters, 1872) belongs to the family Hylidae; group D. parviceps (sensu Faivovich et al., 2005) is distributed in the areas of Atlantic Forest and adjacent Cerrado, from south of Bahia to north of Rio Grande do Sul, concentrated in southeastern region and no description of the function of advertisement call in the literature (Heyer et al., 1990; Forti et al., 2015). In the present study, we describe the vocalizations emitted by Dendropsophus microps present in Serra da Mantiqueira, Campos do Jordão, São Paulo, Brazil and evaluate their functions in the social context of these frogs using playback experiments.

\section{MATERIAL AND METHODS}

This study was carried out in a permanent puddle in Campos do Jordão State Park (PECJ), Campos do Jordão municipality, state of São Paulo, located in Serra da Mantiqueira

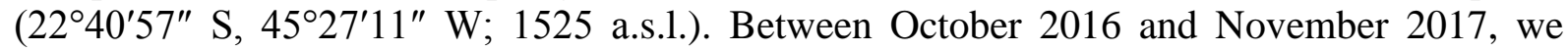
recorded calls from 15 males in natural conditions. From these recordings, we analyzed the following acoustic parameters: call duration, call repetition rate, call interval, note duration, note interval and note repetition rate, number of pulses, pulse duration, interval between pulses, pulse repetition rate, minimum frequency, maximum frequency, dominant frequency.

Playback excerpts were elaborated based on notes chosen from the calls recorded, which presented spectral and temporal values close to the averages obtained for population. Five playback stimuli were used, one for each type of call found in the population and with each stimulus 10 males were tested and recorded. Each individual received only one stimulus, totaling 50 males of $D$. microps tested in this experiment. Field activities started at $8 \mathrm{~h} 00 \mathrm{pm}$, when the choir was already forming, and ended at $2 \mathrm{~h} 00 \mathrm{am}$ when the calling activity decreased. The sampled males had mass ( $\mathrm{g}$ ) and snout-vent length $(\mathrm{mm})$ measured, respectively, using a digital scale with an accuracy of $0.001 \mathrm{~g}$ and a digital pachymeter with an accuracy of $0.01 \mathrm{~mm}$ 
and were collected as a test specimen (license number: SisBio n ${ }^{\circ}$ 54691-2; Instituto Florestal / COTEC SMA Process $n^{\circ} 260108$ - 007.643 / 2016), and were deposited in the Coleção Científica do Laboratório de Zoologia da Universidade de Taubaté (CCLZU / IAM, vouchers 3366 - 3390), Taubaté, São Paulo.

The playback experiments presented the following organization: pre-stimulus / control (60 seconds of recording the individual's activity without interference), playback (60 seconds of stimulus emission for the tested male). Through the focal animal method (Lehner, 1996), we observed and recorded behavioral responses that occurred during the experiment.

For emission of playback stimuli, we used a 20 -watt sound box, positioned $50 \mathrm{~cm}$ away from the resident male; the average sound intensity had been previously adjusted for the $D$. microps population. The sound intensity was adjusted using digital decibel meter DEC-490, with an accuracy of $\pm 1.4 \mathrm{~dB}$, frequency scale from $31.5 \mathrm{~Hz}$ to $8 \mathrm{kHz}$, adjusted to Auto scale level (30dB to $130 \mathrm{~dB}$ ), quick weighting of $125 \mathrm{~ms}$ and frequency weighting $\mathrm{A}(\mathrm{dBA})$.

We counted the acoustic responses emitted by the males in each phase of the playback experiment. We collected the males tested during playback stage, keeping them in the laboratory until the end of the experiments, to avoid, in a previous release, a chance that more than one test was carried out with the same individual. Subsequently, we released the specimens collected at the same capture site.

The differences between the mean emission rates of calls before and during playback stimulus were tested using a t-test for dependent samples (Zar, 1999). All recordings were performed using the Digital Tascam DR-100mkII recorder, mono standard, sampling rate of $44,100 \mathrm{~Hz}, 16$ bit resolution, connected to a Sennheiser ME66 directional external microphone at an average distance of $50 \mathrm{~cm}$ from the individual. All bioacoustics analyzes and playbacks stimulus were made in Raven 1.4 program, with window length $(=$ FFT size $)=246,3 \mathrm{~dB}$ filter bandwidth $=248 \mathrm{~Hz}$, overlap percentage $=50 \%$, and DFT size $=256$, with the Hanning window function. Bioacoustic terminology followed Köhler et al. (2017). The recorded vocalizations were deposited in the IAM sound file of the Laboratório de Zoologia da Universidade de Taubaté, UNITAU.

\section{RESULTS AND DISCUSSION}

We analyzed 605 songs from the 15 male D. microps. Recorded males measured on average $23.9 \mathrm{~mm} \pm 1.8 \mathrm{~mm}(21.2-27.6 \mathrm{~mm})$ in snout-vent length $(\mathrm{SV})$ and average biomass of $0.8 \mathrm{~g} \pm 0.1 \mathrm{~g}(0.6-1.1 \mathrm{~g})$.

The vocalizations emitted by $D$. microps are formed by three distinct types of pulserepetition sounds (Kohler et al., 2017): 1) a simple "A normal" call (Figure 1-A), with only a multi pulsed "A" note; 2 ) an "A fused" call (Figure 1-B) composed of a multi pulsed "A" note and a "f" note represented by a pulse; and, 3) a simple "B" call (Figure 1-C), with a "B" note. This call is accompanied by other " $\mathrm{B}$ " calls, forming a series of calls with regular intervals between them. D. microps combines two series of calls: simple "AA" series (Figure 1-D), with a longer, introductory "A" call, followed by a shorter "A" call; and "AAf" series (Figure 1-E), with a longer introductory "A" call followed by an "Af" call. The values of spectral and temporal parameters of "A", "Af" and "B" calls and of "AA" and "AAf" series are shown in Table 1.

The 50 D. microps males from PECJ emitted all types of vocalizations (calls A, A fused, $\mathrm{B}$ and series AA and AAf); starting vocalizations between $7 \mathrm{~h} 30 \mathrm{pm}$ and $8 \mathrm{~h} 00 \mathrm{pm}$, the interactions decreased between $11 \mathrm{~h} 30 \mathrm{pm}$ and $12 \mathrm{~h} 00 \mathrm{am}$. On days before heavy rains $(>20 \mathrm{~mm})$, when the density of individuals was higher, the vocalizations extended until $02 \mathrm{~h} 00$. It was observed that in the beginning of vocalizations, when there was no chorus formation, individuals started the vocalizations with "B" calls with long intervals between them, in the course of night, as the density of individuals increased, they added call emissions "A", "Af" 
and "AA" and "AAf" series.
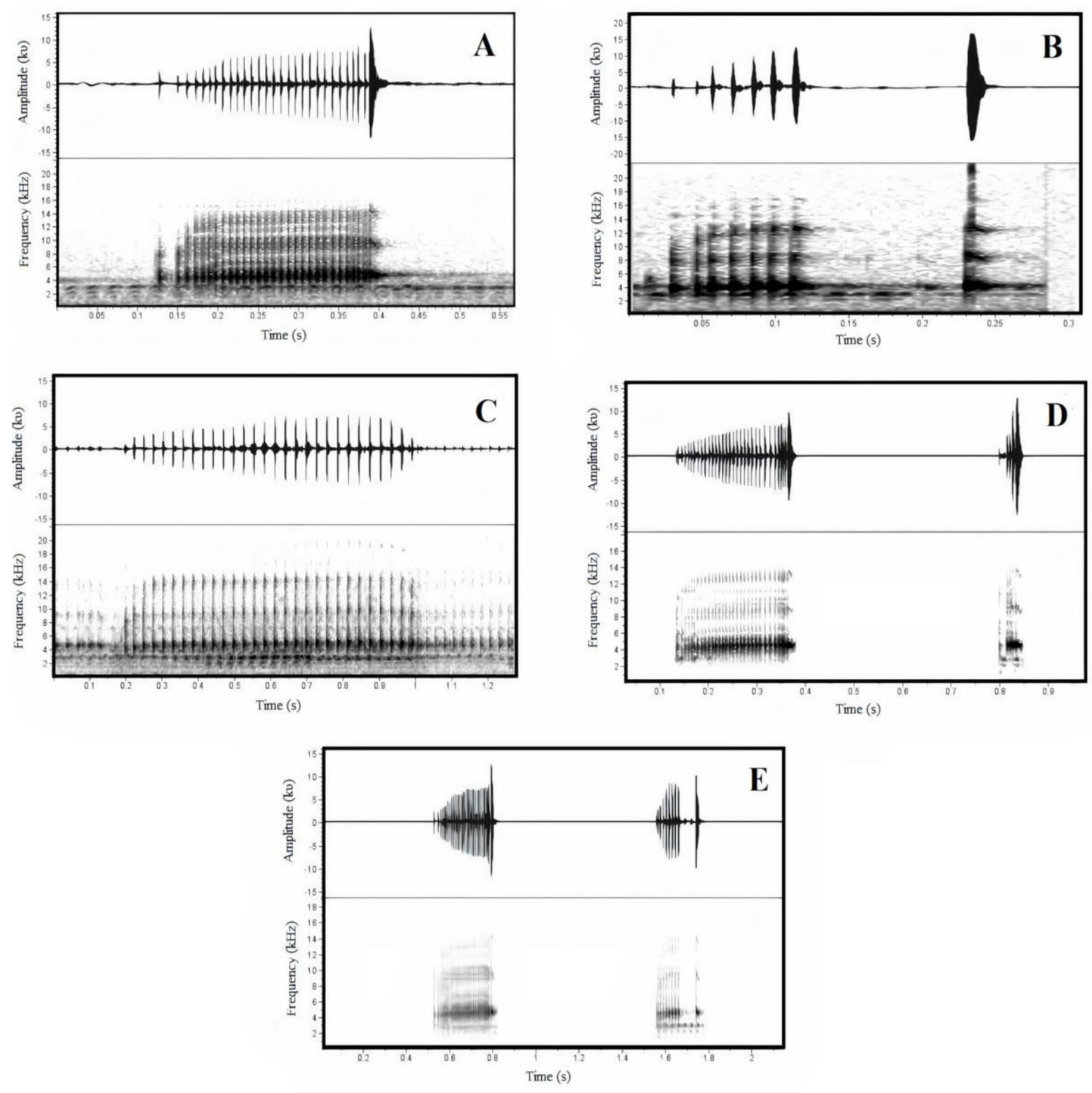

Figure 1. Vocal repertoire of D. microps from Campos do Jordão State Park (calls selected for playback stimuli based on population averages). Oscillogram above and spectrogram below (A) Call "A"; (B) Call "A fused"; (C) Call "B" (advertisement call); (D) "AA" series; (E) "AAf” series. The presence of "side bands" above $7000 \mathrm{~Hz}$ is verified.

A total of 1617 calls were recorded of males submitted to the playback tests. The stimulus phase showed the highest percentage of response, $65.9 \%$ of all calls emitted, followed by the pre-stimulus phase, which gathered $36.1 \%$ of calls emitted by males. The "B" call was emitted in $54.2 \%$ of vocalization cases. Call "B" was also the most emitted in all phases of pre-stimulus and stimulus of the 5 tests performed. The "AAf" series is the least common, representing only $2 \%$ of the total number of calls emitted.

It was observed that when the presence of an intruder emitting stimuli " $A$ ", "B", "Af", "AA" and "AAf" calls was simulated, males start to emit more of "A", "Af" calls "," AA "and" AAf " series ( $\mathrm{t}=-2.57 ; \mathrm{p}=0.047 ; \mathrm{P}<0.05)$ (Figure 2-A). On the other hand, in the stimulus phase, the $B$ call emission rate decreased when compared to the pre-stimulus phase $(t=3.00 ; p$ $=0.043 ; \mathrm{P}<0.05)($ Figure 2-B). 
Table 1. Bioacoustics parameters of Dendropsophus microps calls. The data are expressed as: mean \pm standard deviation and amplitude (min - max). (N) Number of calls analyzed; (s/c/min) series/call per minute; (note / min) note per minute; (pulse / sec) pulses per second.

\begin{tabular}{|c|c|c|c|c|c|c|c|c|}
\hline \multirow[t]{2}{*}{ Call types } & \multirow[t]{2}{*}{ Call "A" } & \multirow[t]{2}{*}{ Call "B" } & \multicolumn{2}{|c|}{ Call "Af" } & \multicolumn{2}{|c|}{ Series "AA" } & \multicolumn{2}{|c|}{ Series "AAf" } \\
\hline & & & Note "A" & Note "f" & $1^{\text {st }}$ Call "A" & $2^{\text {nd }}$ Call " $A$ " & Call "A" & Call "Af" \\
\hline $\mathbf{N}$ & 155 & 244 & 156 & 156 & 35 & 35 & 12 & 12 \\
\hline $\begin{array}{l}\text { Minimum frequency } \\
(\mathbf{H z})\end{array}$ & $\begin{array}{c}4236 \pm 199.7 \\
(3857-4878) \\
\end{array}$ & $\begin{array}{l}4266 \pm 178.04 \\
(3816-4683) \\
\end{array}$ & $\begin{array}{r}4201 \pm 183.6 \\
(3869-4683) \\
\end{array}$ & $\begin{array}{r}4331 \pm 230.1 \\
(3918-4752) \\
\end{array}$ & $\begin{array}{c}4236 \pm 197 \\
(3921-4731) \\
\end{array}$ & $\begin{array}{c}4272 \pm 205 \\
(3821-4731) \\
\end{array}$ & $\begin{array}{c}4017 \pm 77 \\
(3841-4121) \\
\end{array}$ & $\begin{array}{c}4041 \pm 78 \\
(3841-4161) \\
\end{array}$ \\
\hline $\begin{array}{c}\text { Maximum frequency } \\
(\mathbf{H z})\end{array}$ & $\begin{array}{r}4916 \pm 182.6 \\
(4558-5463) \\
\end{array}$ & $\begin{array}{c}4964,6 \pm 193.3 \\
(4366-5523) \\
\end{array}$ & $\begin{array}{r}4925 \pm 146.4 \\
(4439-5544) \\
\end{array}$ & $\begin{array}{r}4876 \pm 177.5 \\
(4484-5156) \\
\end{array}$ & $\begin{array}{c}4885 \pm 177 \\
(4558-5317) \\
\end{array}$ & $\begin{array}{c}4893 \pm 175 \\
(4611-5219) \\
\end{array}$ & $\begin{array}{c}4878 \pm 110 \\
(4682-5082) \\
\end{array}$ & $\begin{array}{c}4862 \pm 100 \\
(4722-5082) \\
\end{array}$ \\
\hline $\begin{array}{c}\text { Dominant frequency } \\
(\mathbf{H z})\end{array}$ & $\begin{array}{c}4600 \pm 192 \\
(4240-5171) \\
\end{array}$ & $\begin{array}{r}4639 \pm 182.8 \\
(4134-5171) \\
\end{array}$ & $\begin{array}{r}4595 \pm 146.4 \\
(4240-4975) \\
\end{array}$ & $\begin{array}{r}4598 \pm 186.9 \\
(4231-4976) \\
\end{array}$ & $\begin{array}{c}4588 \pm 204 \\
(4240-5171) \\
\end{array}$ & $\begin{array}{c}4598 \pm 181 \\
(4240-4929) \\
\end{array}$ & $\begin{array}{c}4501 \pm 62 \\
(4401-4642) \\
\end{array}$ & $\begin{array}{c}4501 \pm 62 \\
(4401-4682) \\
\end{array}$ \\
\hline Series duration (ms) & - & - & - & - & $\begin{array}{c}760 \pm 96 \\
(586-977) \\
\end{array}$ & $\begin{array}{c}760 \pm 96 \\
(586-977) \\
\end{array}$ & $\begin{array}{c}1126 \pm 120 \\
(850-1313)\end{array}$ & $\begin{array}{c}1126 \pm 120 \\
(850-1313)\end{array}$ \\
\hline Call duration (ms) & $\begin{array}{c}206 \pm 88 \\
(28-417) \\
\end{array}$ & $\begin{array}{c}738,8 \pm 138.6 \\
(308-1172) \\
\end{array}$ & $\begin{array}{c}244 \pm 84.7 \\
(119-867) \\
\end{array}$ & $\begin{array}{c}244 \pm 84.7 \\
(119-867) \\
\end{array}$ & $\begin{array}{c}204 \pm 49 \\
(104-309) \\
\end{array}$ & $\begin{array}{c}63 \pm 25 \\
(28-156) \\
\end{array}$ & $\begin{array}{c}250 \pm 34 \\
(197-317) \\
\end{array}$ & $\begin{array}{c}181 \pm 22 \\
(138-210) \\
\end{array}$ \\
\hline Note duration (ms) & $*$ & $*$ & $\begin{array}{r}206 \pm 61.8 \\
(100-667) \\
\end{array}$ & $\begin{array}{l}13 \pm 3.8 \\
(5-20) \\
\end{array}$ & - & - & - & - \\
\hline $\mathrm{N}$ of pulses & $\begin{array}{l}25.2 \pm 13.0 \\
(3-60) \\
\end{array}$ & $\begin{array}{c}28.3 \pm 4.8 \\
(15-46) \\
\end{array}$ & $\begin{array}{c}11.9 \pm 3.8 \\
(7-38) \\
\end{array}$ & 1 & $\begin{array}{c}27 \pm 8 \\
(10-49) \\
\end{array}$ & $\begin{array}{c}6 \pm 1 \\
(3-10) \\
\end{array}$ & $28 \pm 7(19-40)$ & $\begin{array}{c}9 \pm 1 \\
(7-12) \\
\end{array}$ \\
\hline Pulse duration (ms) & $\begin{array}{c}4.1 \pm 1.1 \\
(1.2-7.8) \\
\end{array}$ & $\begin{array}{c}5.3 \pm 1.3 \\
(2.6-9.4) \\
\end{array}$ & $\begin{array}{r}4.3 \pm 1.0 \\
(1.3-7.0) \\
\end{array}$ & $* *$ & $\begin{array}{c}3.4 \pm 1.1 \\
(1-5) \\
\end{array}$ & $\begin{array}{c}4 \pm 1.2 \\
(1-5.7) \\
\end{array}$ & $\begin{array}{l}1.7 \pm 0.4 \\
(1-2.2) \\
\end{array}$ & $\begin{array}{l}2.5 \pm 0.8 \\
(1.2-3.6) \\
\end{array}$ \\
\hline $\begin{array}{c}\text { Intervalo entre pulsos } \\
(\mathrm{ms})\end{array}$ & $\begin{array}{c}4.8 \pm 1.7 \\
(2.2-10.2) \\
\end{array}$ & $\begin{array}{c}21.9 \pm 2.0 \\
(16.2-26.2) \\
\end{array}$ & $\begin{array}{c}10.6 \pm 2.2 \\
(4.5-16.2) \\
\end{array}$ & $* *$ & $\begin{array}{c}4.8 \pm 2.1 \\
(2-9) \\
\end{array}$ & $\begin{array}{c}6.1 \pm 2.4 \\
(3-13) \\
\end{array}$ & $\begin{array}{l}5.9 \pm 1.5 \\
(3.2-9) \\
\end{array}$ & $\begin{array}{c}10 \pm 2 \\
(5-12.5) \\
\end{array}$ \\
\hline $\begin{array}{c}\text { Interval between } \\
\text { pulses (ms) }\end{array}$ & $\begin{array}{l}2921 \pm 4226.8 \\
(214-36054) \\
\end{array}$ & $\begin{array}{c}816 \pm 1762.9 \\
(100-21187) \\
\end{array}$ & $\begin{array}{l}2786 \pm 4064.5 \\
(182-37325) \\
\end{array}$ & $\begin{array}{c}125 \pm 103.4 \\
(37-495)\end{array}$ & $\begin{array}{c}417 \pm 50 \\
(349-485) \\
\end{array}$ & $\begin{array}{c}417 \pm 50 \\
(349-485) \\
\end{array}$ & $\begin{array}{c}695 \pm 120 \\
(440-892) \\
\end{array}$ & $\begin{array}{c}695 \pm 120 \\
(440-892) \\
\end{array}$ \\
\hline $\begin{array}{c}\text { Series/call repetition } \\
\text { rate }(\mathrm{s} / \mathrm{c} / \mathrm{min})\end{array}$ & $\begin{array}{l}25.5 \pm 13.0 \\
(4.5-66.4) \\
\end{array}$ & $\begin{array}{c}50.4 \pm 11.6 \\
(31.7-96.1) \\
\end{array}$ & $\begin{array}{l}30.5 \pm 20.4 \\
(6.3-97.1) \\
\end{array}$ & $\begin{array}{l}30.5 \pm 20.4 \\
(6,3-97.1) \\
\end{array}$ & $\begin{array}{c}24.6 \pm 13.4(6.9 \\
-52.2) \\
\end{array}$ & $\begin{array}{c}24.6 \pm 13.4(6.9 \\
-52.2) \\
\end{array}$ & $\begin{array}{c}21.1 \pm 15.9(7.7 \\
-52.2) \\
\end{array}$ & $\begin{array}{l}21.1 \pm 15.9 \\
(7.6-52.2) \\
\end{array}$ \\
\hline $\begin{array}{c}\text { Note repetition rate } \\
(\text { nota/min) }\end{array}$ & $*$ & $*$ & $\begin{array}{l}32.2 \pm 20.4 \\
(6.1-90.7) \\
\end{array}$ & $\begin{array}{l}35.3 \pm 26.4 \\
(6.3-95.3) \\
\end{array}$ & - & - & - & - \\
\hline $\begin{array}{c}\text { Pulse repetition rate } \\
\text { (pulse/sec) }\end{array}$ & $\begin{array}{c}121.7 \pm 34.7 \\
(58.0-234.5) \\
\end{array}$ & $\begin{array}{c}38.76 \pm 4.7 \\
(32.6-76.9) \\
\end{array}$ & $\begin{array}{c}50.8 \pm 14.5 \\
(25.6-152.0) \\
\end{array}$ & $* *$ & - & - & - & - \\
\hline $\begin{array}{l}\text { Average sound } \\
\text { intensity }(\mathrm{dB})\end{array}$ & 79 & 74 & 79 & 79 & 79 & 79 & 79 & 79 \\
\hline
\end{tabular}

* Call represented only by a note, value is the same in relation to the call.

** Note represented by just one pulse, the value is the same in relation to the note. 

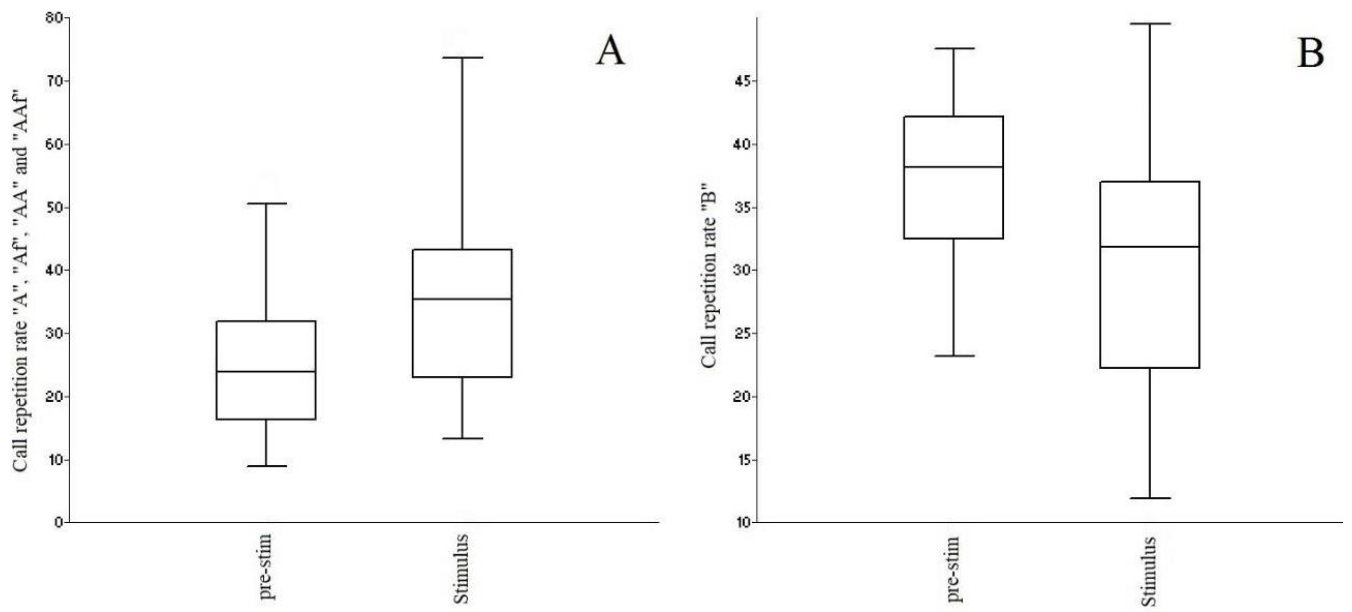

Figure 2. Average repetition rates (y-axis) of the "A", "Af", B and "AA" and "AAf" calls emitted by Dendropsophus microps males in the pre-stimulus and stimulus phases.

During the experiments, we recorded five events of reproductive behavior with amplexus formation; in all cases when the female approached, the resident male changed the emission of " $A$ " and "Af" calls to only "B" calls. We also observed eight males performing visual signaling ("toe trembling" sensu Hödl and Amézquita, 2001) lifting one of the forelimbs. Six individuals were emitting " $\mathrm{A}$ " and "Af" calls before performing the signaling behavior and all eight individuals were less than $10 \mathrm{~cm}$ from the nearest male. We also observed three incidents of physical fighting between males of $D$. microps. During these confrontations, there were emissions of a series represented by a sequence of 4 to 5 short " $A$ " calls with duration ranging from $44 \mathrm{~ms}$ to $88 \mathrm{~ms}$ (average $66.5 \pm 20.1 \mathrm{~ms}$ ), with intervals ranging from $303 \mathrm{~ms}-473 \mathrm{~ms}$ (average $397.7 \pm 60.9 \mathrm{~ms}$ ) between the calls (Figure 3). Two individuals in response to the "Af" stimuli and one individual in response to the "AAf" stimulus also emitted this call series.

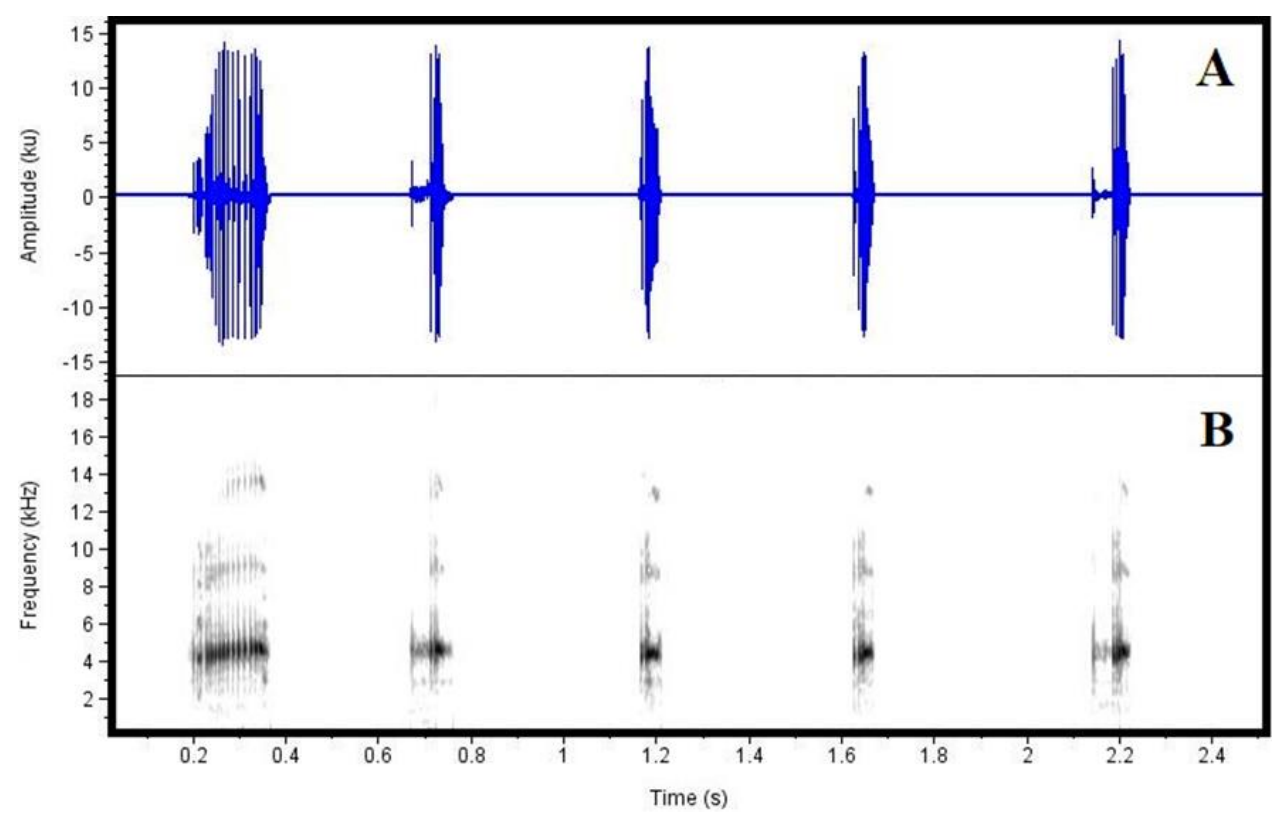

Figure 3. Series emitted by a resident male of Dendropsophus microps in response to the presence of an invading male in the Campos do Jordão State Park, Campos do Jordão, São Paulo. (A) Oscillogram (B) Spectrogram. The presence of "side bands" above $7000 \mathrm{~Hz}$ is verified.

D. microps modifies its acoustic behavior in response to a co-specific stimulus, due to the difference between the average repetition rates emitted in the phases of playback experiment. 
When we simulate the presence of an intruder, we observe a decrease in repetition rates of call $\mathrm{B}$ from the control phase to the stimulus phase. It was possible to observe that not only during the playback tests but also in the descriptions of the advertisement call of the species, the "B" call was the most emitted among all the other notes. This call was emitted in all types of context: at the beginning of vocalizations, with low or high density population, when there was the proximity to females, at the peak and at the end of the vocalizations. The "B" call, therefore, was qualified as the advertisement call (sensu, Wells, 1977) of D. microps, because in addition to being the most emitted call, it was related to the amplexus and proximity to the females.

The stimulus "A", "A fused", "AA" and "AA fused" presented similar behavioral responses to each other. In all stimuli, there was an increase in the repetition rate of " $A$ ", "Af" and series "AA" and "AAf".

We identified the "A", "Af" calls and the "AA" and "AAf" series as aggressive calls, since the stimuli with these calls caused a reduction in the emission of advertisement calls and increased emissions of calls similar to the stimulus. Call " $A$ " was inserted in a series of aggressive calls expressed by the resident male in response to an intruder male. They were related to agonistic behavior, with the emission of visual signals and preceding physical fighting.

The data found for D. microps in Campos do Jordão differ, considering the identification of call functions, from those found by Heyer et al. (1990) and by Forti et al. (2015) in Boracéia, since these works do not present an updated nomenclature (Köhler et al., 2017). According to Köhler et al. (2017), a call is a unit of vocalization, which is separated from another call by a period of silence, which is longer than the duration of the call itself. In these descriptions (Heyer et al., 1990; Forti et al., 2015), it is possible to observe that the authors were registering a note what was actually a call. Thereby, to perform a comparison between the values of acoustic parameters found for D. microps in PECJ and the values found by Heyer et al. (1990) and Forti et al. (2015) new interpretations with updated nomenclatures are needed, as well a review of most of the descriptions published before the work of Köhler et al. (2017) for the D. parviceps group.

When compared, populations of D. microps showed similarities between spectral parameters of the calls, considering frequency range and dominant frequency. The "A" call in individuals from Campos do Jordão presents a similar amplitude of frequency $3857-5463 \mathrm{~Hz}$ in comparison to those found by Forti et al. (2015) in Boracéia, $4574-5452 \mathrm{~Hz}$, and in Ribeirão Branco, 4513 - $5398 \mathrm{~Hz}$. Besides, the dominant frequency found for individuals from Campos do Jordão, $4600 \pm 192 \mathrm{~Hz}$, is similar to the dominant frequency found by Heyer et al. (1990), $4500-5800 \mathrm{~Hz}$. The "B" call emitted by individuals from Campos do Jordão presented a similar amplitude of frequency $3816-5523 \mathrm{~Hz}$. Concerning the individuals from Boracéia, the amplitude was 4513 - $5580 \mathrm{~Hz}$, and of Ribeirão Branco, 4458 - $5226 \mathrm{~Hz}$ (Forti, 2015). When comparing dominant frequencies, the "B" calls also showed similarities, $4639 \pm 182.78 \mathrm{~Hz}$ in the present study, corroborating the dominant frequency found by Heyer et al. (1990), 4700 $5500 \mathrm{~Hz}$.

With correct interpretations of the works of Heyer et al. (1990) and Forti et al. (2015), following Köhler et al. (2017), the three populations of $D$. microps presented calls with similar temporal characteristics. The "A" call has an average note duration of $206 \mathrm{~ms}$, fitting the length range presented by Heyer et al., (1990) 200 - $350 \mathrm{~ms}$. The "B" call has an average duration of $738.8 \mathrm{~ms}$, being longer than the note duration found by Heyer et al., (1990) $500-600 \mathrm{~ms}$. The average pulse repetition rate of the " $\mathrm{A}$ " call was 121.7 pulses per second, similar to what was sampled by Heyer et al. (1990), 100 - 150 pulses per second, and by Forti et al. (2015), 60 203 pulses per second. Call "B" shows an average pulse repetition rate of 38.8 pulses per second, consistent with that found by Forti et al. (2015), 23 - 60 pulses per second, but less than that found by Heyer et al. (1990), 45 - 55 pulses per second. The "Af" call had an average 
duration of $244 \mathrm{~ms}$ and an average pulse repetition rate of 50.8 pulses per second.

Heyer et al. (1990), in his work with individuals from Boracéia, suggested that "note A" was the advertisement call, while "note B" was the aggressive call. Considering this, it was expected that, when the presence of an intruder was simulated via playback, "B" calls emissions would increase in response to the stimulus, while "A" calls emissions would decrease in response to the stimulus. What we found in the present study was the exact opposite of this, however. Heyer et al. (1990) did not test the call function in his work, and performed the description with a few individuals.

Nali and Prado (2014), in their work with Bokermannohyla ibitiguara, registered that, in response to artificial stimuli, with the function of sending an aggressive message, these individuals increase the duration as the number of aggressive calls emitted. They also registered that in cases of proximity to the female, this species reduces the emission of aggressive calls and starts to emit an advertisement call more often. Wells and Schwartz (1984) also reported that Dendropsophus ebraccatus adds secondary notes to the advertisement call in response to an intruder in their territory, in addition to increasing the number of notes emitted, and is probably a common feature between the groups Dendropsophus microcephalus and Dendropsophus leucophyllatus. Wells (1988) corroborates these results by recording this same behavior occurring with Dendropsophus microcephalus and Dendropsophus phlebodes. For D. microps, this behavior was also observed, the "Af" call and the "AA" and "AAf" series are described for the first time in the present study and despite presenting a different physical structure from the A call, such as the presence of two notes composing the song, a pulse repetition rate lower than the "A" call, we consider these songs as variations of call "A" with additions of secondary notes (Wells and Schwartz, 1984). In the present study, with the introduction of artificial stimuli, D. microps individuals start to respond with a higher repetition rate of aggressive calls, and with a decrease in the emission of the advertisement call (Wells and Schwartz, 1984). The "B" call was the most emitted in all phases of the five experiments; moreover, it was observed that, with the proximity of the female, there is an exchange of " $\mathrm{A}$ ", "Af" call emissions between the nearby males, for the emission of "B" calls. These results suggest that the " $\mathrm{B}$ " call is the advertisement call, since its main function is the attraction of cospecific females (Gerhardt, 1982).

Aggressive calls (sensu Bogert, 1960) are emitted by males who intend to defend a specific resource within their territory, when a male invades the resident male's territory (Toledo and Haddad, 2005; Wells, 2007). The playback tests in this study corroborate results from previous studies, since the stimulus increased the emission of aggressive calls. D. microps in the present study also emitted a series of "A" calls when an intruder male approached a resident male, suggesting that this is a territorial call (Toledo et al., 2014).

The emission of acoustic signals by anurans is the best-known form of intraspecific communication (Wells, 2007). However, individuals of some species present emission of different visual signals within the social context, which can be considered an alternative and a complement to acoustic communication (Amézquita and Hödl, 2004). These are usually used by daytime species for reproductive behavior and aggressive interactions (Lindquist and Hetherington, 1996; Haddad and Giaretta, 1999), but also, can be used by anurans in low-light conditions (Amézquita and Hödl, 2004; Hartmann et al., 2004; 2005; Giasson and Haddad, 2006). Amézquita and Hödl (2004) in their study with D. parviceps, report that this species uses both visual and acoustic signals to emit aggressive messages and explain that toe trembling plays a fundamental role in the expression of these messages in agonistic interactions. In the present study, we can observe that $D$. microps also uses visual signaling to perform aggressive interactions, since this behavior was observed in conjunction with the emission of aggressive calls (notes "A", "Af") and with the proximity of invading males. 


\section{CONCLUSION}

Identifying the function of different types of signals emitted by a species is important to understanding interactions within a social context. Dendropsophus microps already had its advertisement call described, but its function in intraspecific social interactions had not been tested, which reinforces the effectiveness of the playback methodology in identifying call function and encourages other studies to use the same procedure. Thus, this study provides information relevant to the descriptive and acoustic behavioral biology of the species.

\section{ACKNOWLEDGEMENT}

We thanks São Paulo Research Foundation (FAPESP) for the financial support that provided all material for making the recordings (\#2013/50741-7). MHRT thanks Capes for the scholarship.

\section{REFERENCES}

AMÉZQUITA, A.; HÖDL, W. How, when, and where to perform visual displays: the case of the Amazonian frog Hyla parviceps. Herpetologica, v. 60, p. 420-429, 2004. https://doi.org/10.1655/02-51

BOGERT, C. M. The influence of sound on the behavior of amphibians and reptiles. In: LANYON, W. W.; TAVOLGA, W. W. Animal sounds and communication. Port Jervis: Lubrecht and Cramer, 1960. p.137-320.

FAIVOVICH, J.; HADDAD, C. F. B.; GARCIA, P. C. A.; FROST, D. R.; CAMPBELL, J. A.; WHEELER, W. C. Systematic review of the frog family Hylidae, with special reference to Hylinae: Phylogenetic analysis and taxonomic revision. Bulletin of the American Museum of Natural History, v. 294, p. 1-240, 2005. https://doi.org/10.1206/00030090(2005)294[0001:SROTFF]2.0.CO;2

FORTI, L. R.; MÁRQUEZ, R.; BERTOLUCI, J. Advertisement call of Dendropsophus microps (Anura: Hylidae) from two populations of southeastern Brazil. Zoologia, v. 32, p. 187-194, 2015. https://doi.org/10.1590/S1984-46702015000300002

GERHARDT, H. C. Sound pattern recognition in some North American tree frogs (Anura: Hylidae): implications for mate choice. American Zoologist, v. 22, p. 581 - 595, 1982. https://doi.org/10.1093/icb/22.3.581

GERHARDT, H. C.; HUBER, F. Acoustic Communication in Insects and Anurans: common problems and diverse solutions. Chicago: The University of Chicago press, 2002. p. 531.

GIASSON, L. O. M.; HADDAD, C. F. B. Social interactions in Hypsiboas albomarginatus (Anura: Hylidae) and the significance of acoustic and visual signals. Journal of Herpetology, v. 40, p. 171-180, 2006. https://doi.org/10.1670/205-05A.1

HADDAD, C. F. B.; GIARETTA, A. Visual and acoustic communication in the Brazilian torrent frog, Hylodes asper (Anura: Leptodactylidae). Herpetologica, v. 55, p. 324-333, 1999. https://dx.doi.org/10.2307/3893226

HARTMANN, M. T.; HARTMANN, P. A.; HADDAD, C. F. B. Visual signaling and reproductive biology in a nocturnal treefrog, genus Hyla (Anura: Hylidae). AmphibiaReptilia, v. 25, p. 395-406, 2004. https://doi.org/10.1163/1568538042788933 
HARTMANN, M. T.; GIASSON, L. O. M.; HARTMANN, P. A.; HADDAD, C. F. B. Visual communication in Brazilian species of anurans from the Atlantic Forest. Journal of $\begin{array}{llllll}\text { Natural History, } & \text { v. 39, p. }\end{array}$ https://doi.org/10.1080/00222930400008744

HEYER, W, R.; RAND, A. S.; CRUZ, C. A. G.; PEIXOTO, O. L.; NELSON, C. Frogs of Boracéia. Arquivos de Zoologia, v. 31, n. 271-272, 1990. https://doi.org/10.11606/issn.2176-7793.v31i4p231-410

HÖDL, W.; AMÉZQUITA, A. Visual signaling in anura amphibians. In: RYAN, M. J. (ed.). Anuran Communication. Washington, DC: Smithsonian Institution Press, 2001. p. 121141.

KÖHLER, J.; JANSEN, M.; RODRÍGUEZ, A.; KOK, P. J. R.; TOLEDO, L. F.; EMMRICH, M.; GLAW, F.; HADDAD, C. F. B.; RÖDEL, M. O.; VENCES, M. The use of bioacoustics in anuran taxonomy: theory, terminology, methods and recommendations for best practice. Zootaxa, v. 4251, n. 1, p. 1-124, 2017.

LEHNER, R. N. Handbook of ethological methods. United Kingdom: Cambridge University Press, 1996. P. 38-54p.

LINDQUIST, E. D.; HETHERINGTON, T. E. Field studies on visual and acoustic signaling in the earless Panamanian golden frog, Atelopus zeteki. Journal of Herpetology, v. 30, p. 347-374, 1996. https://dx.doi.org/10.2307/1565171

NALI, R. C.; PRADO, C. P. A. Complex call with different messages in Bokermannohyla ibitiguara (Anura, Hylidae) a gladiator frog of the Brazilian Cerrado. Journal of Herpetology, v. 48, n. 3, p. 407-414, 2014. https://dx.doi.org/10.1670/13-090

TOLEDO, L. F.; HADDAD, C. F. B. Acoustic repertoire and Calling Behavior of Scinax fuscomarginatus (Anura, Hylidae). Journal of Herpetology, v. 39, n. 3, p. 455- 464, 2005. https://doi.org/10.1670/139-04A.1

TOLEDO, L. F.; HADDAD, C. F. B. Defensive vocalizations of neotropical anurans. South American Journal of Herpetology, v. 4, n. 1, p. 25-42, 2009. https://doi.org/10.2994/057.004.0104

TOLEDO, L. F.; MARTINS, I. A.; BRUSCHI, D. P.; PASSOS, M. A.; ALEXANDRE, C.; HADDAD, C. F. B. The anuran calling repertoire in the light of social context. Acta Ethologica, n. 2, p. 87-99, 2014. https://doi.org/10.1007/s10211-014-0194-4

WELLS, K. D. The courtship of frogs. In: TAYLOR, D. H.; GUTTMAN, S. I. (eds.). The reproductive biology of amphibians. New York: Plenum Press, 1977. p. 233-262.

WELLS, K. D. The effect of social interactions on anurans vocal behavior. In: FRITZSCH, B.; WALKOWIAK, W.; HETHERINGTON, T.; WILCZYNSKI, W.; RYAN, M. (eds.). The evolution of the amphibian auditory system. New York: John Wiley and Sons, 1988. p. $433-454$.

WELLS, K. D. The ecology and behavior of amphibians. 1. ed. Chicago: The University of Chicago Press, 2007.

WELLS, K. D.; SCHARTZ, J. J. Vocal communication in a Neotropical treefrog, Hyla ebraccata: advertisement calls. Animal Behaviour, v. 32, p. 405-420, 1984. https://doi.org/10.1016/S0003-3472(84)80277-8 ZAR, J. H. Biostatistical analysis. 4. ed. Upper Saddle River: Prentice-Hall, 1999. 931 p. 